\title{
Prevention of tumour cell apoptosis associated with sustained protein kinase $B$ phosphorylation is more sensitive to regulation by insulin signalling than stimulation of proliferation and extracellular signal-regulated kinase
}

\author{
Christoph Schmid $^{1}$ - Claudia Ghirlanda ${ }^{1}$ Markus Niessen ${ }^{1,2}$ (1)
}

Received: 4 October 2016 / Accepted: 4 March 2017 / Published online: 18 March 2017

(C) The Author(s) 2017. This article is published with open access at Springerlink.com

\begin{abstract}
Insulin controls blood glucose while insulinlike growth factor (IGF) 1 is an important growth factor. Interestingly, both hormones have overlapping bioactivities and can activate the same intracellular signal transduction cascades. Growth control (mainly by IGF1) and metabolic function (predominantly by insulin) are believed to depend on activation of extracellular signal-regulated kinases (ERKs) $1 / 2$ and protein kinase B (Akt/PKB), respectively. Therefore, insulin analogues that are used to normalize blood glucose are tested for their ability to preferentially activate Akt/PKB but not ERK1/2 and mitogenesis. Growth hormone, IGF1, and hyperinsulinemia are associated with increased risk of growth progression of some cancer types. To test if continuous exposure to insulin can favour tumour growth, we studied insulin/IGF1-dependent activation of ERK1/2 and Akt/PKB by Western blotting, inhibition of apoptosis by ELISA, and induction of proliferation by $\left[{ }^{3} \mathrm{H}\right]$-thymidine incorporation in Saos-2/B10 osteosarcoma cells. IGF1 and insulin both induced proliferation and prevented apoptosis effectively. Regulation of apoptosis was far more sensitive than regulation of proliferation. IGF1 and insulin activated PKB (Akt/PKB) rapidly and consistently
\end{abstract}

Electronic supplementary material The online version of this article (doi:10.1007/s11010-017-2996-y) contains supplementary material, which is available to authorized users.

Christoph Schmid

christoph.schmid@usz.ch

1 Division of Endocrinology, Diabetology and Clinical Nutrition, University Hospital of Zurich, Raemistrasse 100, 8091 Zurich, Switzerland

2 Competence Centre for Systems Physiology and Metabolic Diseases, Swiss Federal Institute of Technology (ETH) Zurich, 8093 Zurich, Switzerland maintained its phosphorylation. Activation of ERK1/2 was only observed in response to IGF1. Loss of p-Akt/PKB (but not of p-ERK1/2) was associated with increased apoptosis, and protection from apoptosis was lost when activation of Akt/PKB was inhibited. These findings in Saos-2/B10 cells were also replicated in the A549 cell line, originally derived from a human lung carcinoma. Therefore, IGF1 and insulin more likely (at lower concentrations) enhance tumour cell survival than proliferation, via activation and maintenance of phosphatidylinositol 3-kinase activity and p-Akt/PKB.

Keywords Osteosarcoma cells $\cdot$ IGF1 $\cdot$ Insulin · Apoptosis $\cdot$ PI3K $\cdot$ Obesity

\section{Introduction}

Sufficient fuel and nutrient supply and growth hormone (GH) action are important for normal growth; in vivo, insulin and insulin-like growth factor (IGF) 1 are intrinsically linked to anabolic, growth-friendly conditions. Obesity and acromegaly are deleterious conditions, associated with high insulin and IGF1 levels, and decreased life expectancy. Obesity is characterized by increased fat mass, insulin resistance, hyperinsulinemia, and an increased risk not only for type 2 diabetes but also for cancer; acromegaly is also characterized by insulin resistance but with decreased fat mass, and an excess of GH, insulin, and IGF1. Although the presence of anabolic hormones is usually perceived to be favourable, it has been realized that decreased action of $\mathrm{GH}$, insulin, and IGF1 can increase life span and reduce tumour cell growth [1-3].

In vitro, insulin and IGF1 promote growth. Insulin was found to favour growth of breast cancer cells [4], and 
insulin increases proliferation of the MCF-7 breast cancer cell line [5-9], and IGF1 is a potent mitogen for osteosarcoma cells $[8,10-18]$. These properties of insulin and IGF1 could underlie increased growth of breast cancer in obesity and of osteosarcoma in puberty. Insulin and IGF1 share mitogenic pathways, including the mitogen-activated protein kinase (MAPK), extracellular signal-regulated kinase (ERK) and the phosphatidylinositol 3-kinase (PI3K) pathways [8, 11]. Receptors for IGF1 (IGF1R) and insulin (IR) and their downstream signal transduction pathways thus became therapeutic targets [19].

Dietary restriction decreases circulating levels of insulin and IGF1, is antitumorigenic and increases life-span. The PI3K pathway may mediate the sensitivity of selected tumours to dietary restriction as tumours sensitive to dietary restriction were growth-responsive to insulin and IGF1 whereas tumours with constitutively active PI3K signalling were not. Decreased PI3K signalling in human tumour xenografts correlated better with dietary restriction-induced apoptosis than with decreased proliferation; enhanced apoptosis was shown to contribute to net tumour cell growth suppression [20].

We analysed in more detail antiapoptotic effects of insulin and IGF1 in two tumour cell lines, A549 non-small-cell lung cancer (NSCLC) and Saos-2/B10 osteoblastic osteosarcoma cells, with a special focus on the latter since they have been found to be critically dependent on insulin-like signals for proliferation and especially survival in vitro. Saos-2/B10 cells have been used to assess cancer-related safety of insulin analogues (IR binding agonists) with a focus on mitogenic potency, receptor activation and binding studies [13]. Increased affinity for the IGF1R was found to be strongly correlated with increased mitogenic potency as also confirmed by later studies [21]. Glargine, e.g., the first modified insulin to delay absorption and to prolong duration of action, has a 6-8-fold increased affinity for IGF1R and mitogenic potency compared with insulin [13, 21]. Nevertheless, glargine is considered as safe, because it is converted to metabolites M1 and M2 with decreased activities at both IGF1R and IR but an apparently more favourable ratio of metabolic-mitogenic potency than the native compound [22-25].

Overall, concentrations of insulin and insulin analogues in vivo (in healthy individuals and in patients with diabetes) are normally low compared to the levels required to elicit a mitogenic response. As indicated above, tumour growth could depend on both, regulation of apoptosis and mitogenesis. We therefore analysed in more detail antiapoptotic effects of insulin and IGF1 in the Saos-2/B10 cell line which was found to be critically dependent on insulin-like signals for proliferation and especially survival in vitro. We compared the effects of insulin and IGF1 to those of glargine and those of FCS, tested the interference of IGF-binding protein (IGFBP) 3 (inhibitor of IGF1) and of wortmannin (WT, inhibitor of PI3K), and analysed the signal transduction pathways involved.

\section{Materials and methods}

\section{Cell culture}

Saos-2 is an osteosarcoma cell line which was originally derived from a 14-year-old female (ATCC HTB 85, American Type Culture Collection. Rockville, MD); it was characterized in more detail and subcloned to yield the osteoblastic osteosarcoma line Saos-2/B10 [26, 27]. These cells are p53-negative $[14,28]$ and produce no IGF1 $[10$, 29]. They were passaged in Falcon tissue culture flasks in DMEM/Ham's F-12 medium (Gibco 31885/21765) containing $50 \mu \mathrm{g} / \mathrm{ml}$ gentamicin, $2 \mathrm{mmol} / \mathrm{l} \mathrm{L}$-glutamine, and $10 \%(\mathrm{v} / \mathrm{v}) \mathrm{FCS}$ at $37{ }^{\circ} \mathrm{C}$ in an atmosphere of $5 \% \mathrm{CO}_{2}$. Cells (passage 16-33) were cultured in DMEM [50 $\mu \mathrm{g} /$ $\mathrm{ml}$ gentamicin, $2 \mathrm{mmol} / \mathrm{l} \mathrm{L}$-glutamine and 5\% (v/v) FCS] for 3 days prior to the start of experiments. A549 is a lung (alveolar cell) adenocarcinoma cell line which was originally derived from a 58-year-old Caucasian male (ATCC, Rockville, MD; ECACC no. 86012804) [10, 30]. A549 cells belong to the family of NSCLC cells and to the adenocarcinoma histological subtype with epithelial origin. They contain wild-type p53 [31]. These cells were cultured (passage 7-24) in Falcon tissue culture flasks in RPMI (Gibco 31870) containing $2 \mathrm{mM}$ L-glutamine, $50 \mu \mathrm{g} / \mathrm{ml}$ gentamicin, and $10 \%(\mathrm{v} / \mathrm{v}) \mathrm{FCS}$ at $37{ }^{\circ} \mathrm{C}$ in an atmosphere of $5 \% \mathrm{CO}_{2}$.

Under serum-free conditions, Ham's F-12 medium was used with $1 \mathrm{~g} / \mathrm{l}$ free fatty acid-free BSA (from Sigma, St. Louis, MO, USA). IGF1 was from Ciba-Geigy, Basel, Switzerland, insulin from Novo Nordisk, Gentofte, Denmark, and the insulin analogue glargine from SanofiAventis, Frankfurt, Germany. rhIGFBP3 and pharmacological inhibitors of PI3K (WT: Sigma, Buchs, Switzerland) or MEK (UO126 or PD98059: Sigma, Buchs, Switzerland) were added as indicated.

\section{Assessment of proliferation}

Cells $\left(21 \times 10^{3}\right.$ per $\left.\mathrm{cm}^{2}\right)$ were plated in $5 \%$ FCS-containing medium. After 3 days of growth, confluent cultures were rinsed with serum-free medium, and incubated for $18 \mathrm{~h}$ in serum-free Ham's F-12 medium containing $1 \mathrm{~g} / \mathrm{l}$ BSA and growth factors as indicated. DNA synthesis was measured by methyl- $\left[{ }^{3} \mathrm{H}\right]$-thymidine (Amersham, $89 \mathrm{Ci} / \mathrm{mmol}$; $0.5 \mu \mathrm{Ci}$ per dish) incorporation during a 3-h pulse following exposure to test media for 18-21 $\mathrm{h} \mathrm{[32].}$ 


\section{Assessment of apoptosis}

Cells were plated as described for proliferation, washed, and incubated for $4 \mathrm{~h}$ in serum-free Ham's F-12 medium containing $1 \mathrm{~g} / \mathrm{l} \mathrm{BSA}$; growth factors and test compounds were added as shown in Fig. 1a.

Cells were washed with ice-cold PBS, and lysed into $400 \mu \mathrm{l}$ of kit lysis buffer and centrifuged for $10 \mathrm{~min}$ at $200 \times g$ at room temperature. A $20 \mu \mathrm{l}$ volume was used for analysis (Cell Death Detection ELISA ${ }^{\text {PLUS }}$ from Boehringer Mannheim) following the manufacturer's instructions [29, 32]. This method measures cytosolic oligonucleosomebound DNA and allows quantitative determination of histone-associated DNA fragments. It is based on a sandwich-enzyme immunoassay which detects enrichment of mono- and oligonucleosomes in the cytoplasmic fraction of cell lysates by monoclonal antibodies directed against DNA and histones [29].

\section{Immunoblotting}

Cells were lysed in $50 \mathrm{mmol} / \mathrm{l}$ HEPES pH 7.5, $140 \mathrm{mmol} / \mathrm{l}$ $\mathrm{NaCl}, 1 \mathrm{mmol} / \mathrm{l} \mathrm{PMSF}, 0.5 \%$ Triton X-100, $10 \mathrm{mmol} / \mathrm{l} \mathrm{NaF}$, $1 \mathrm{mmol} / \mathrm{l} \mathrm{Na}{ }_{2} \mathrm{H}_{2} \mathrm{P}_{2} \mathrm{O}_{7}, 1 \mathrm{mmol} / \mathrm{l} \mathrm{Na} \mathrm{O}_{4} \mathrm{~V}, 3 \mu \mathrm{g} / \mathrm{ml}$ aprotinin, $3 \mu \mathrm{g} / \mathrm{ml}$ leupeptin. Equal amounts of protein (concentration determined using the bicinchoninic acid protein assay kit from Pierce) were separated by SDS-PAGE (NuPAGE, Invitrogen) and transferred onto nitrocellulose membranes. $2 \%$ Non-fat milk in TBST $[10 \mathrm{mmol} / \mathrm{l}$ Tris-HCl, $\mathrm{pH} 7.4$, $150 \mathrm{mmol} / \mathrm{l} \mathrm{NaCl}, 0.05 \%$ (v/v) Tween 20] was used to block nonspecific binding of antibodies to membranes. Incubation with primary and secondary antibodies was either at room temperature for $1 \mathrm{~h}$ or overnight at $4{ }^{\circ} \mathrm{C}$. Immuno-reactive proteins were visualized by the LumiLight Western blotting substrate (Roche) using a LAS-3000 imaging system (Fuji). Signal intensities were quantified using the AIDA software package (Raytest). Equal loading
Fig. 1 Flow diagram of experimental protocols. Cells were grown in FCS-containing media for 3 days and exposed to serum-free, albumin-containing test media as shown. Apoptosis was assessed after $4 \mathrm{~h}$ (a, "common stop") by an ELISA detecting cytosolic oligonucleosomes. Insulin/IGF1 signalling was analysed by Western blotting using antibodies against the unphosphorylated and phosphorylated forms of IR-IGF1RIRS1 (not shown), Akt/PKB and ERK1/2, and actin, with "common stop" (a) and with "common start" (b) protocols as indicated a

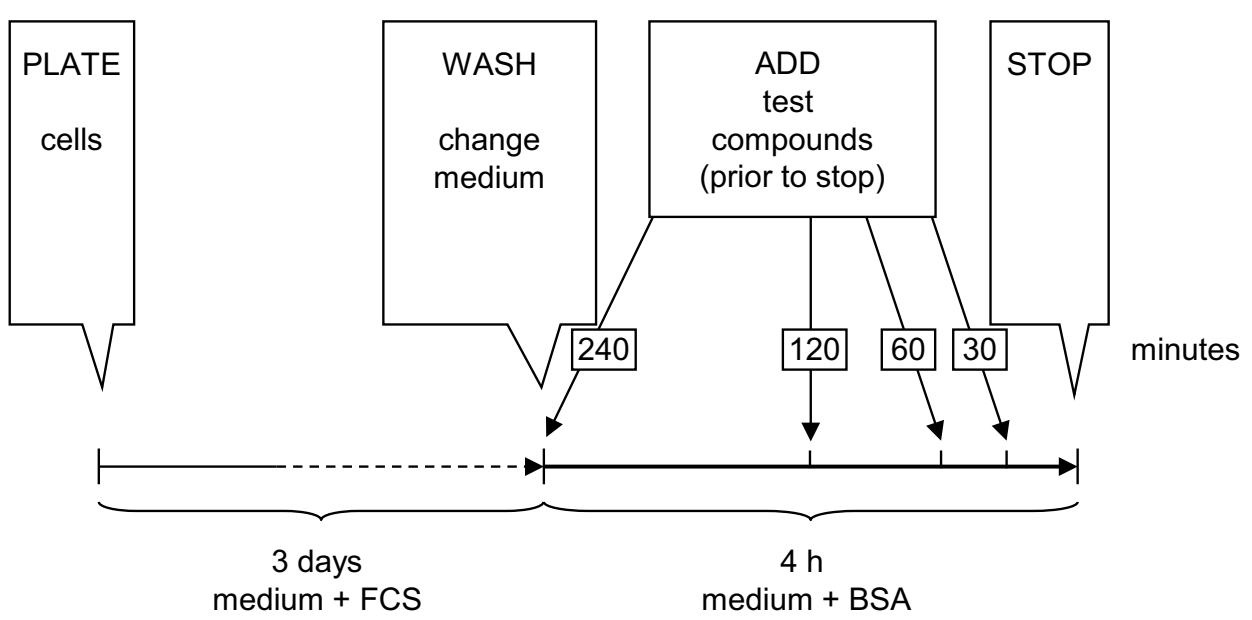

b

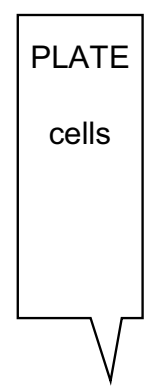

"common STOP"

"common START"

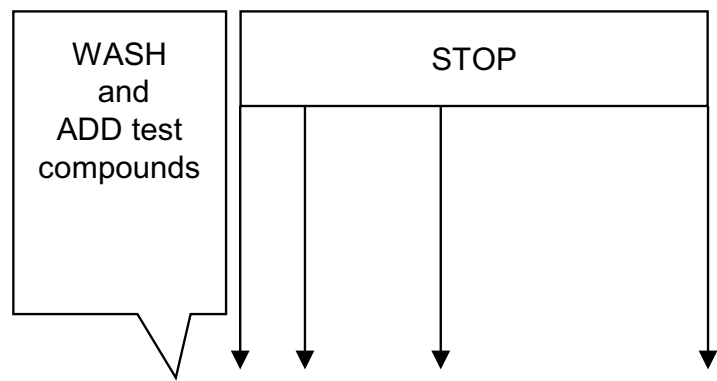

$30 \quad 60 \quad 120$

240 minutes

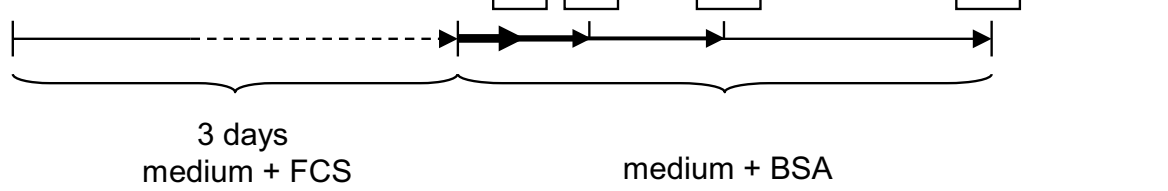


and transfer were confirmed with an antibody against actin (MAB1501: EMD Millipore, Temecula, USA). Insulin/ IGF-dependent signalling was assessed with antibodies against the phosphorylated forms of Akt/protein kinase B (PKB; Ser473: Cell Signaling, Danvers, USA) and ERK1/2 (Thr202/Tyr204: Cell Signaling, Danvers, USA). Activation of IR and IGF1R was monitored using an antibody against p-Tyr (clone 4G10, EMD Millipore, Temecula, USA). Expression levels of Akt/PKB, ERK1/2, IR, IGF1R, IRS1, actin, and LC3A/B were assessed with specific antibodies [Akt/PKB: BD Transduction Laboratories, San Jose, USA; ERK1/2: Cell Signaling, Danvers, USA; insulin R $\beta$, IGF1R $\beta$, and IRS1: Santa Cruz, Dallas, USA; actin: clone C4, MAB1501, Millipore/Merck, Darmstadt, Germany; LC3A/B: (DRU4C) Rabbit mAb, Cell Signaling, Danvers, USA].

\section{Statistical analysis and presentation of data}

At least three Western blots with duplicates or at least five ELISA or ${ }^{3} \mathrm{H}$-incorporation studies (carried out in triplicate), respectively, were combined. Data are expressed as means \pm SEM. In the case of Western blots, results of quantifications are plotted on a log scale normalized to protein amount and relative to control; values were highly consistent between experiments regardless of normalization to protein (as loaded), total (phosphorylated plus nonphosphorylated proteins) Akt/PKB and ERK/
MAPK or actin. Statistical significance was assessed by the unpaired two-sided Student's $t$-test or by ANOVA. $p<0.05$ was considered statistically significant.

\section{Results}

\section{Insulin and IGF1 increase proliferation and potently inhibit apoptosis in Saos-2/B10 cells}

Insulin and IGF1 stimulated $\left[{ }^{3} \mathrm{H}\right]$-thymidine incorporation into DNA in a dose-dependent manner, with increasing concentrations up to the same maximum (Fig. 2a). IGF1 was more potent and half-maximal stimulation was reached at lower concentrations of IGF1 $(0.4 \mathrm{nmol} / \mathrm{l})$ compared to insulin $(20 \mathrm{nmol} / \mathrm{l})$.

Serum withdrawal results in apoptosis of Saos-2/ B10 cells within hours. Inclusion of IGF1 or IGF2 in test media protects Saos-2/B10 cells against apoptosis $[29,32]$. We wanted to test if inclusion of insulin had a similar effect. Figure $2 \mathrm{~b}$ shows dose-response curves for insulin and IGF1. Lower doses of IGF1 or insulin were sufficient to inhibit apoptosis compared to DNA synthesis. IGF1 was more potent compared to insulin with half-maximal values at 0.04 versus $1.0 \mathrm{nmol} / \mathrm{l}$ for insulin. IGF1 (at $1 \mathrm{nmol} / \mathrm{l}$ ) and insulin (at $100 \mathrm{nmol} / \mathrm{l}$ ) decreased apoptosis to a similar extent.
Fig. 2 Insulin and IGF1 regulate proliferation and apoptosis of Saos-2/B10 cells. a Stimulation of $\left[{ }^{3} \mathrm{H}\right]$-thymidine incorporation into DNA by IGF1 and insulin. Cells were grown in 5\% FCS-containing media for 3 days and exposed to serum-free, albumin-containing test media, containing IGF1 or insulin. DNA synthesis was measured by a $\left[{ }^{3} \mathrm{H}\right]$-thymidine pulse $18-21 \mathrm{~h}$ following exposure to test media $(n=6)$. $\mathbf{b}$ Inhibition of apoptosis by IGF1 and insulin. Cells were exposed to test media containing IGF1 or insulin as shown in Fig. 1a. Apoptosis was assessed after $4 \mathrm{~h}$. Results are expressed relative to control $(n=5)$
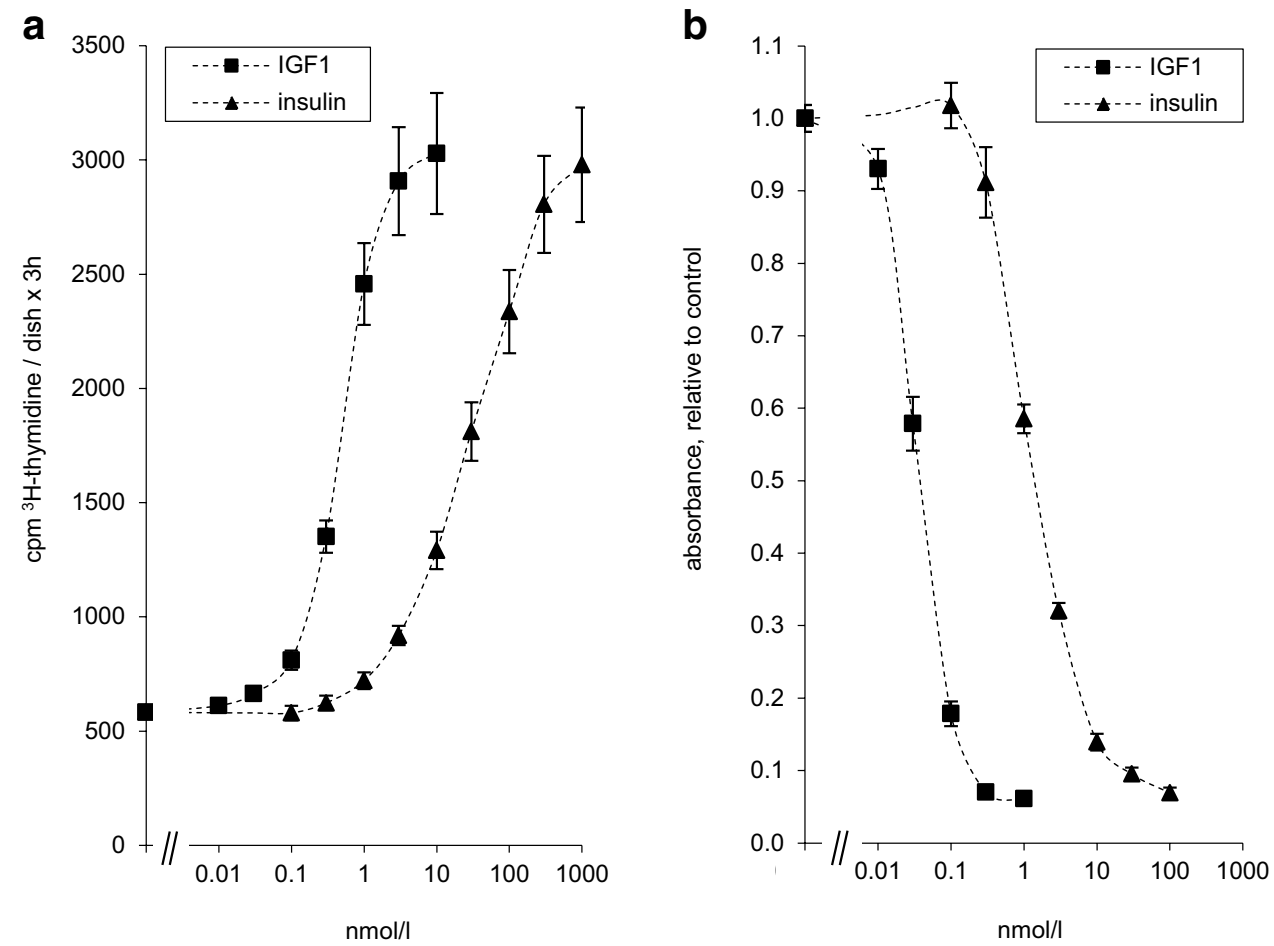
Insulin and IGF1 activate Akt/PKB and ERK1/2 in Saos-2/B10 cells: time and dose dependence

Activation of insulin/IGF1-dependent signalling in Saos-2/B10 cells was studied with phospho-specific antibodies against Akt/PKB (p-Ser473) and ERK1/2 (p-Thr202/Tyr204). Time dependence and dose dependence were analysed (Figs. 3, 4, respectively). IGF1 and insulin both activated Akt/PKB strongly within minutes; sustained activation of $\mathrm{Akt} / \mathrm{PKB}$ was observed in

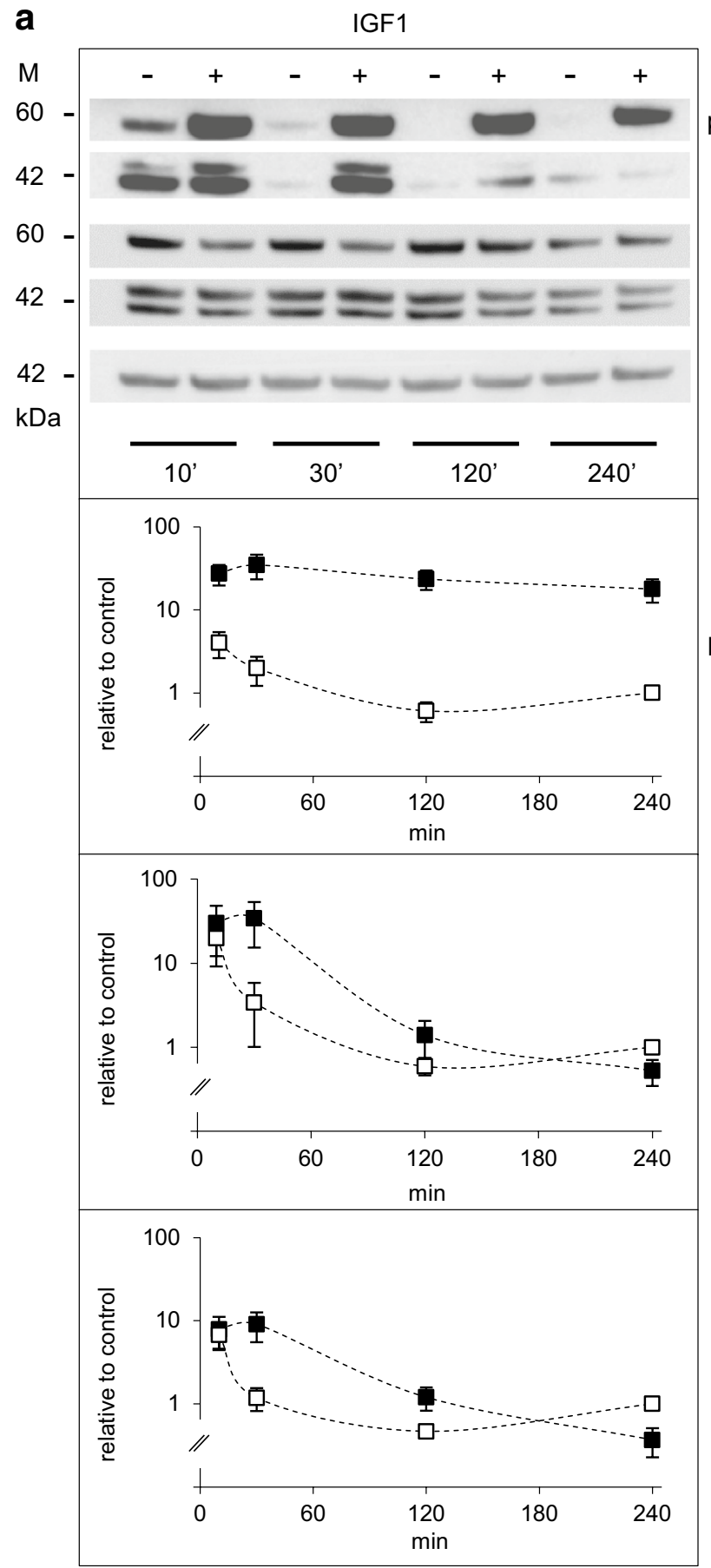

Fig. 3 Time-dependent activation of Akt/PKB and ERK1/2 by IGF1 and insulin in Saos-2/B10 cells. Representative Western blots are shown on top; quantification of signals from at least four independent experiments below. Abundance of $\mathrm{p}-\mathrm{Akt} / \mathrm{PKB}$ and $\mathrm{p}-\mathrm{ERK} 1 / 2$ is b
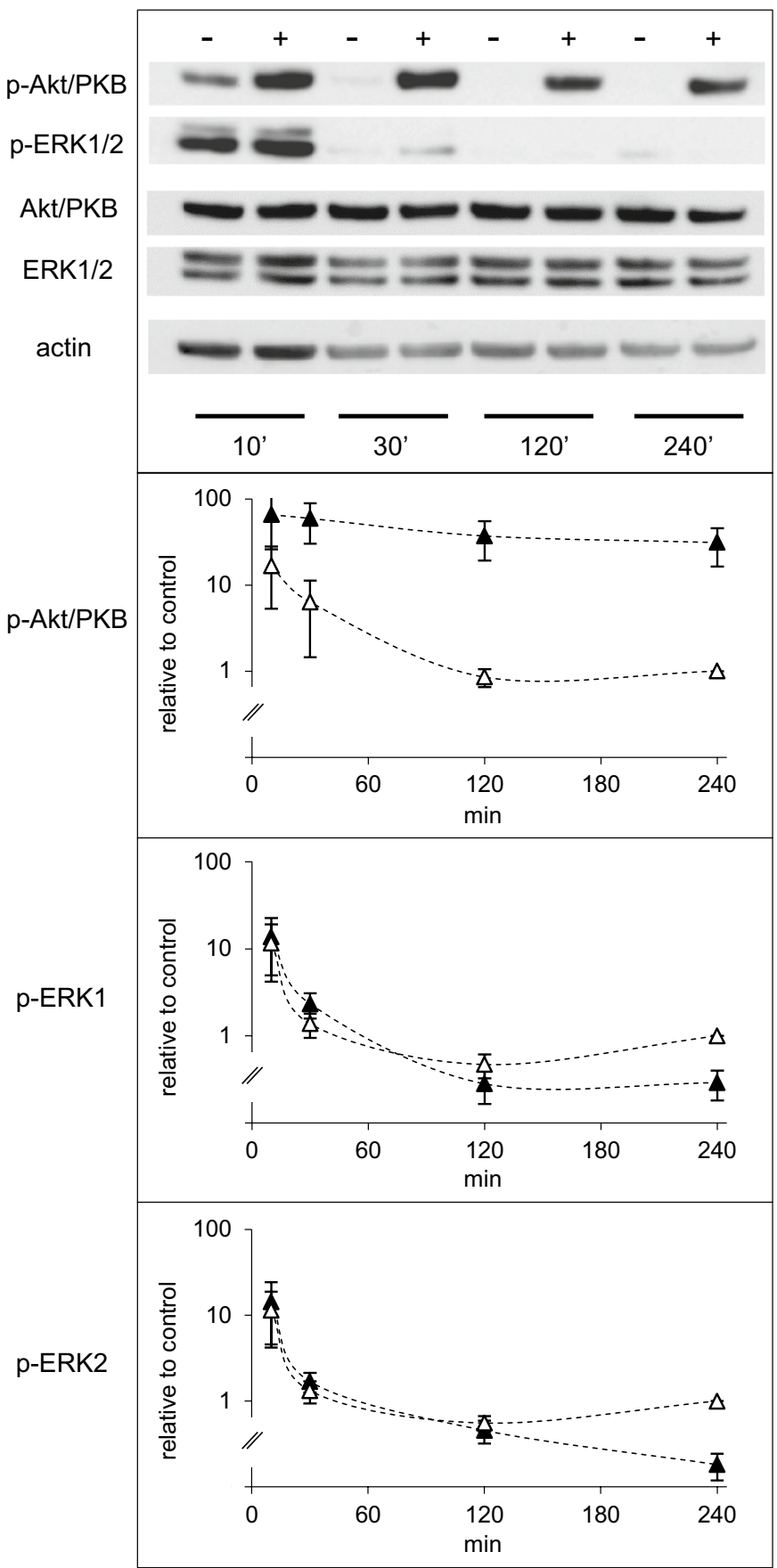

shown relative to control $(4 \mathrm{~h})$. Cells were exposed to vehicle (empty symbols), to $1 \mathrm{nmol} / \mathrm{l} \mathrm{IGF1} \mathrm{(filled} \mathrm{squares)} \mathrm{or} \mathrm{to} 100 \mathrm{nmol} / \mathrm{l}$ insulin (filled triangles) as outlined in Fig. 1b, and incubations were stopped after 10, 30, 120, and $240 \mathrm{~min}$ 


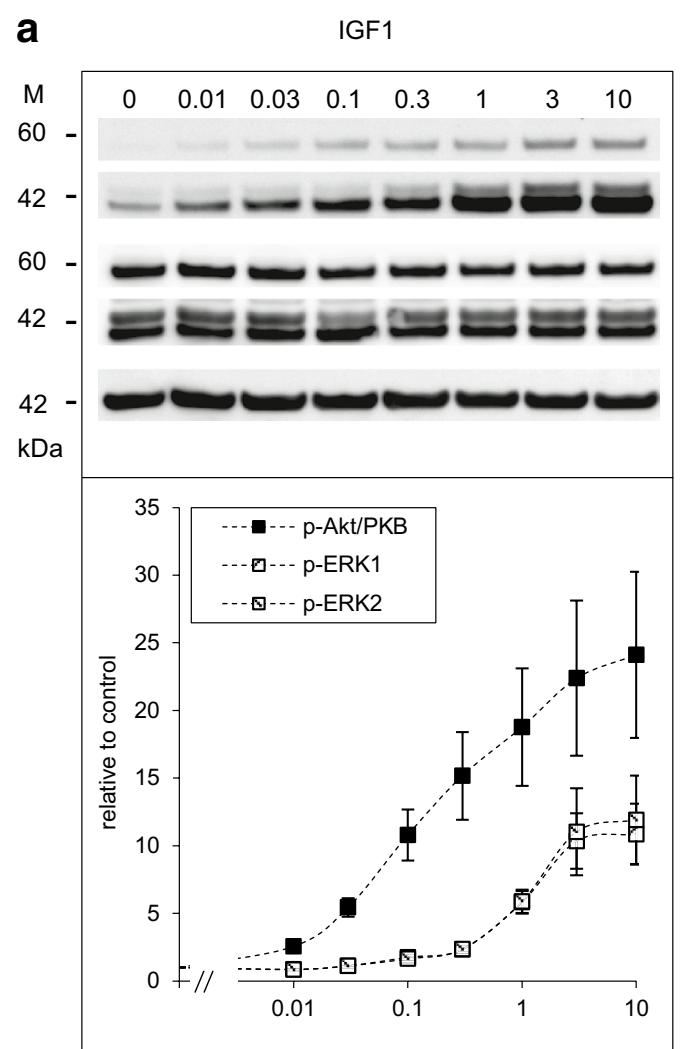

Fig. 4 Dose-dependent activation of Akt/PKB and ERK1/2 by IGF1 and insulin in Saos-2/B10 cells. Cells were exposed to IGF1 (a) and insulin (b) for $30 \mathrm{~min}$ as described in Fig. 1 b (common start). Rep-

response to both IGF1 and insulin while ERK1/2 activation was rather transient, and only observed in response to IGF1 (Fig. 3b). We consistently observed a decrease in phosphorylation of ERK1/2 after longer exposures $(4 \mathrm{~h})$, and insulin was more effective than IGF1 in this regard. Quantification of at least seven independent experiments is shown with numerical values (plotted on a log scale) in the lower panels.

Dose-dependent phosphorylation/activation of Akt/ PKB and ERK1/2 after 30 min of exposure to IGF1 or insulin is shown in Fig. 4. IGF1 was more potent in phosphorylating Akt/PKB than insulin. The dose-response curves are broad, and our data cannot reveal whether maximal stimulation of $\mathrm{p}-\mathrm{Akt} / \mathrm{PKB}$ was achieved at $10 \mathrm{nmol} / \mathrm{l} \mathrm{IGF1;} \mathrm{maximal} \mathrm{activation} \mathrm{was} \mathrm{not} \mathrm{reached} \mathrm{at}$ $100 \mathrm{nmol} / \mathrm{l}$ insulin, the highest concentration that was tested; thus, concentrations required for half-maximal stimulation of $\mathrm{Akt} / \mathrm{PKB}\left(\mathrm{EC}_{50}\right)$ cannot be given. ERK1/2 phosphorylation dependent on stimulation with IGF1 was much less pronounced compared to Akt/PKB, and insulin even at high concentrations barely increased p-ERK1/2. b insulin

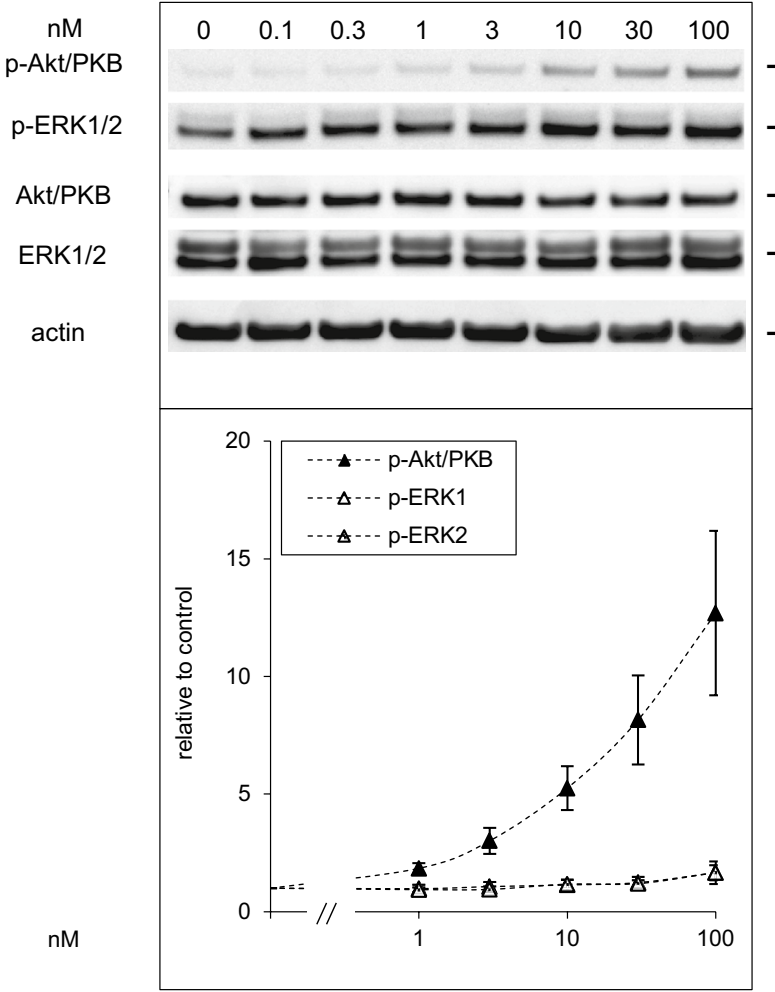

resentative Western blots are shown on top, below quantification of at least four independent experiments. Abundance of $\mathrm{p}-\mathrm{Akt} / \mathrm{PKB}$ and $\mathrm{p}$-ERK1/2 is expressed relative to control

\section{Time-dependent inhibition of apoptosis in Saos-2/B10 cells by IGF1 and insulin}

To test how long after serum withdrawal cells could be rescued from apoptosis, IGF1 or insulin were added to supernatants at different time points after serum withdrawal. Maximal inhibition of apoptosis was observed when IGF1 or insulin (or glargine, not shown) was added at least $2 \mathrm{~h}$ prior to the end of the 4-h incubation time (Fig. 5), i.e., not later than $2 \mathrm{~h}$ after serum withdrawal. At this time point, residual Akt/PKB phosphorylation in serum- and hormone-free control conditions was low (Fig. 3). IGF1 or insulin promptly increased Akt/PKB phosphorylation at all tested time points, i.e., also with the protocol of Fig. 1a, "common stop", as well as with the protocol of Fig. 1b, "common start". ERK1/2 was activated after short-term exposure to IGF1; strikingly, after 4-h exposure, p-ERK was consistently decreased in cells exposed to IGF1 or (more clearly) insulin, relative to control (Figs. 3, 5). 


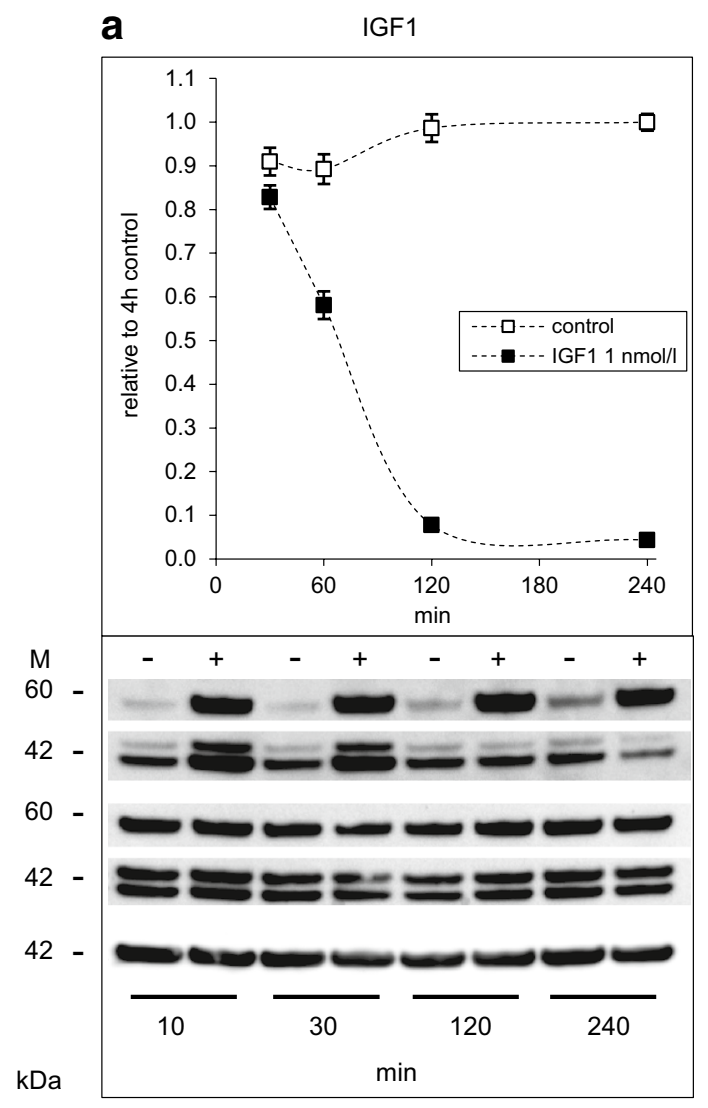

Fig. 5 Time-dependent inhibition of apoptosis and activation of signalling by IGF1 and insulin in Saos-2/B10 cells. Cells were cultured in serum-free media for the last $4 \mathrm{~h}$ as shown in Fig. 1a (common stop). IGF1 (a, $1 \mathrm{nmol} / \mathrm{l})$ or insulin $(\mathbf{b}, 100 \mathrm{nmol} / \mathrm{l})$ was added to the

\section{IGFBP3 inhibits IGF1- but not insulin-dependent regulation of apoptosis in Saos-2/B10 cells}

rhIGFBP3 can effectively block IGF1-induced proliferation and survival in cell culture experiments [17, 29, 32, 33]. In order to test whether apoptosis was regulated by IGF1 and insulin also in the presence of IGFBP3, cells were serum-deprived for $4 \mathrm{~h}$ in the absence or presence of IGF1, insulin, or glargine. $10 \mathrm{nmol} / \mathrm{l}$ rhIGFBP3 was added to the cells $30,60,120$, or $240 \mathrm{~min}$ prior to the end of incubation (Fig. 6). Apoptosis was not changed in Saos-2/B10 cells exposed to rhIGFBP3 alone. $10 \mathrm{nmol} / \mathrm{l}$ rhIGFBP3 did not inhibit the apoptosis-preventing effects of $100 \mathrm{nmol} / 1$ insulin [32] and of $1 \mathrm{nmol} / 1$ glargine but selectively inhibited the apoptosis-preventing effects of $1 \mathrm{nmol} / \mathrm{l} \mathrm{IGF} 1 ; 10 \mathrm{nmol} / \mathrm{l}$ rhIGFBP3 was effective (in the presence of IGF1) if added at least 120 min prior to the end of the $4 \mathrm{~h}$ incubation time. Correspondingly, rhIGFBP3 blocked Akt/PKB phosphorylation dependent on incubation with $1 \mathrm{nmol} / \mathrm{l}$ IGF1 but not with $100 \mathrm{nmol} / 1$ insulin or $1 \mathrm{nmol} / \mathrm{l}$ glargine (not shown).

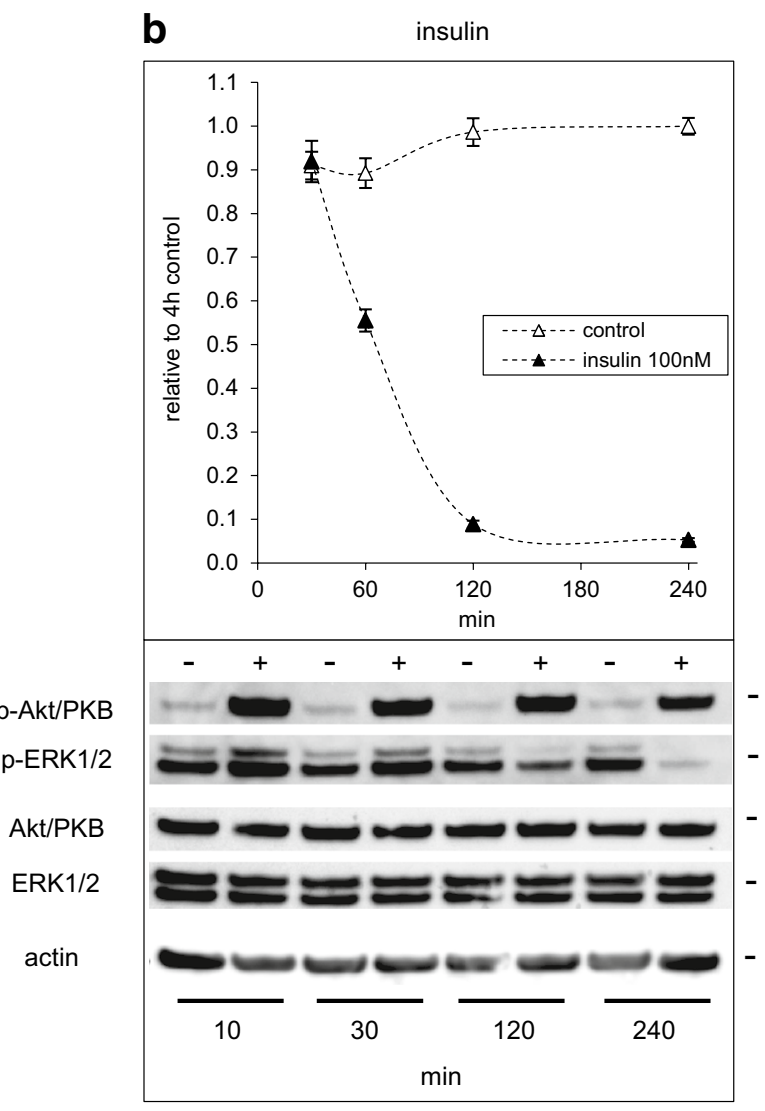

media $30 \mathrm{~min}, 1 \mathrm{~h}, 2 \mathrm{~h}$, or $4 \mathrm{~h}$ prior to stop. Apoptosis is shown at the top (expressed relative to $4 \mathrm{~h}$ control; $n=5$ ), representative Western blots in lower panels

\section{Wortmannin inhibits IGF1- and insulin-dependent regulation of apoptosis in Saos-2/B10 cells}

To test if activation of Akt/PKB and/or ERK1/2 are required for insulin/IGF1-dependent regulation of apoptosis in Saos-2/B10 cells, we used WT and UO126/ PD98059 to inhibit their activation, respectively. We first confirmed by Western blotting that preincubating cells with these inhibitors for $10 \mathrm{~min}$ prior to exposure to $1 \mathrm{nmol} / \mathrm{l} \mathrm{IGF} 1$ or $100 \mathrm{nmol} / \mathrm{l}$ insulin for $30 \mathrm{~min}$ blocked activation of Akt/PKB and/or ERK1/2. 100 (but not 20) nmol/l WT reliably blocked Akt/PKB phosphorylation, and $50 \mu \mathrm{mol} / \mathrm{l}$ UO126 or $20 \mu \mathrm{mol} / \mathrm{l}$ PD98059 blocked ERK phosphorylation under these conditions (not shown). WT (Fig. 7) but not UO126 or PD98059 (both not shown) interfered with protection from apoptosis by both IGF1 and insulin. WT had to be present for $4 \mathrm{~h}$ for this effect; however, more than half-maximal protection from apoptosis was still found when WT was added only for the last $3 \mathrm{~h}$. In addition, cells cultured for $4 \mathrm{~h}$ in the presence of WT showed reduced activation of Akt/PKB 
Fig. 6 Time-dependent interference of IGFBP3 with apoptosis inhibition by IGF1 and glargine in Saos-2/B10 cells. Cells were cultured in serum-free media for $4 \mathrm{~h}$ in the absence or presence of $1 \mathrm{nmol} / \mathrm{l}$ IGF1 (a, $n=5)$ or $1 \mathrm{nmol} / 1$ glargine $(\mathbf{b}, n=3)$ as shown in Fig. 1a (common stop). IGFBP3 $(10 \mathrm{nmol} / \mathrm{l})$ was added $30 \mathrm{~min}$, $1 \mathrm{~h}, 2 \mathrm{~h}$, and $4 \mathrm{~h}$ prior to stop $(n=5)$

Fig. 7 Time-dependent interference of wortmannin with apoptosis inhibition by IGF1 and insulin in Saos-2/B10 cells. Cells were cultured in serumfree media containing $1 \mathrm{nmol} / 1$ IGF1 $(\mathbf{a}, n=5)$ or $100 \mathrm{nmol} / 1$ insulin $(\mathbf{b}, n=3)$, as shown in Fig. 1a (common stop). WT (100 nmol/l) was added 1, 2, 3, and $4 \mathrm{~h}$ prior to stop a

IGF1

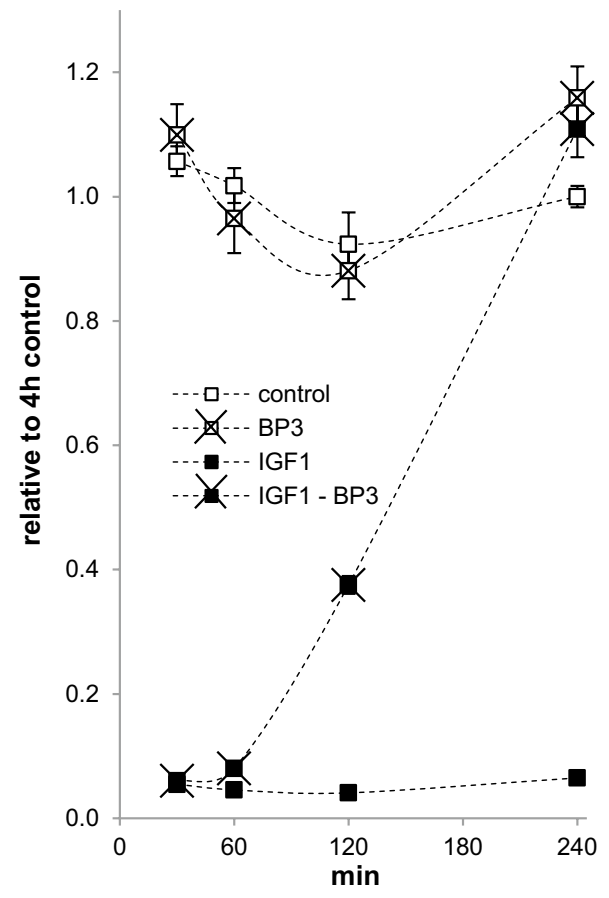

a

IGF1

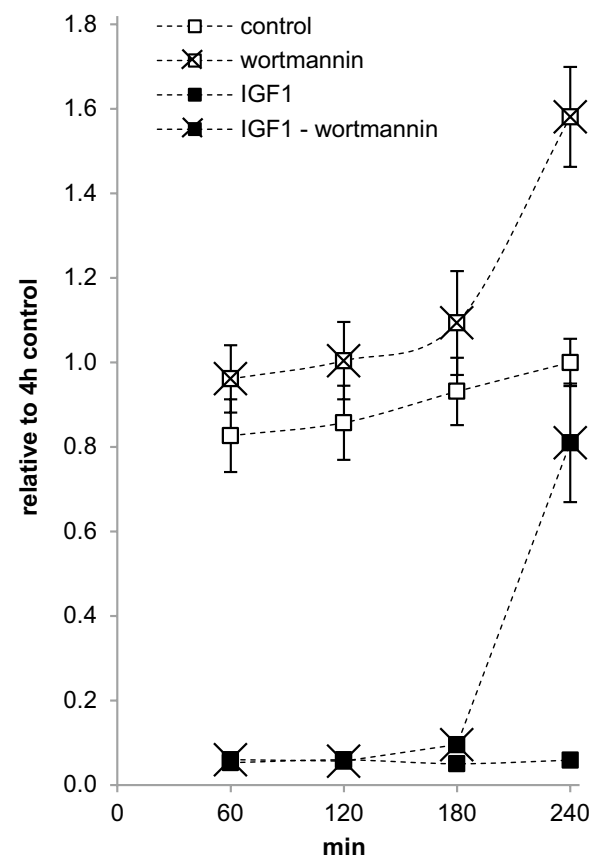

b

glargine

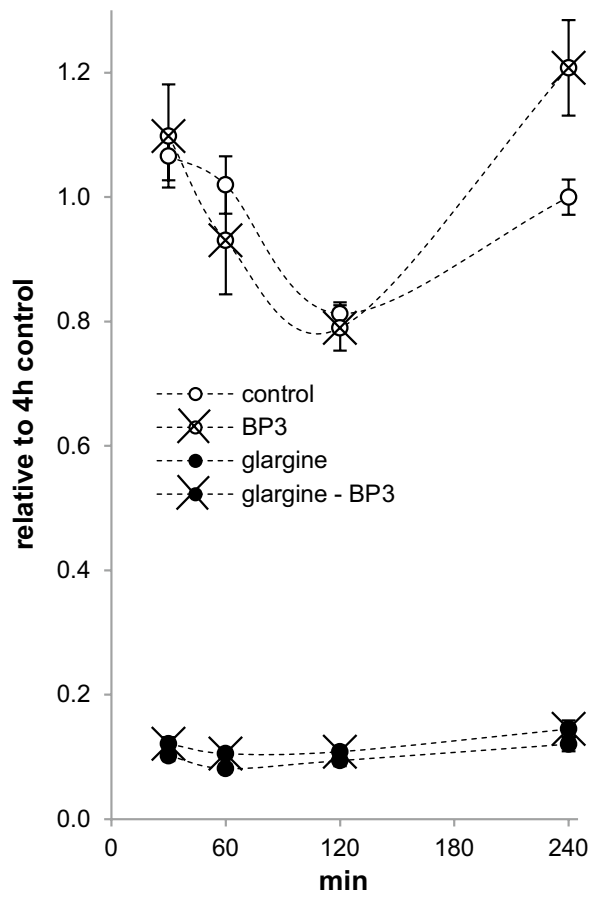

b

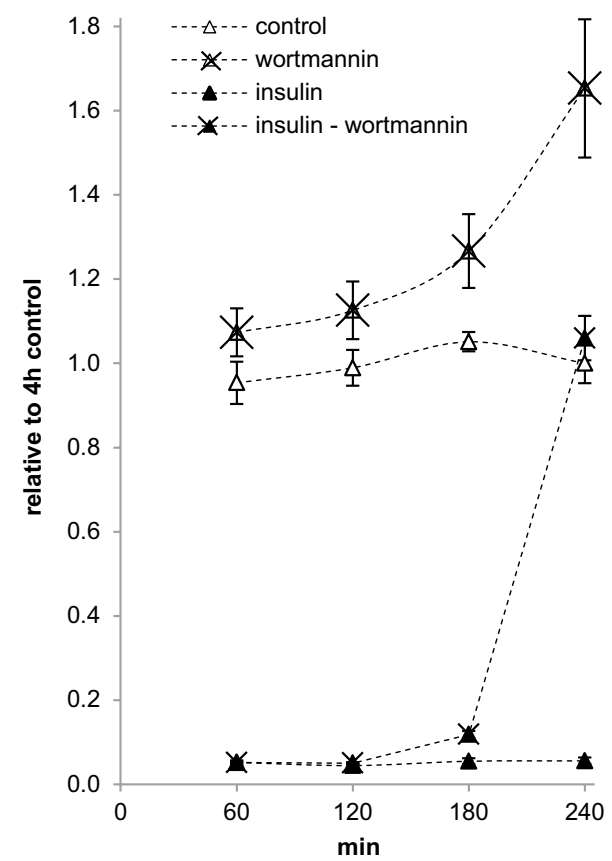

by IGF1 and by insulin but marked phosphorylation of Akt/PKB was still observed when WT was added only for the last $3 \mathrm{~h}$ (not shown). WT alone, when present throughout $4 \mathrm{~h}$, increased apoptosis in the control condition (Fig. 7).

\section{Comparing effects of IGF1 and insulin with those of glargine and FCS in Saos-2/B10 cells}

As in the case of IGF1 (low doses) and insulin (high doses), exposure of Saos-2/B10 cells to glargine also resulted 
in activation of $\mathrm{Akt} / \mathrm{PKB}$ and protection from apoptosis (Fig. 8). Significant effects on apoptosis (but not on proliferation) were seen in response to $0.1 \mathrm{nmol} / 1$ glargine. Likewise, concerning activation of Akt/PKB and ERK1/2, it appeared that the potency of glargine was intermediate between that of IGF1 and insulin. FCS (5\%) tended to be more effective in activating ERK1/2 and in stimulating DNA synthesis, but it tended to be less potent than IGF1 and insulin in protecting Saos-2/B10 cells from apoptosis and increasing $\mathrm{p}-\mathrm{Akt} / \mathrm{PKB}$.

\section{Insulin and IGF1 regulate proliferation and apoptosis in A549 cells}

In order to test if our findings in Saos-2/B10 can be reproduced in another human cell line, we repeated a subset of our experiments with A549 cells [10,30].

First we analysed time- (Fig. 9) and dose-dependent (Fig. 10, top panel) regulation of Akt/PKB and ERK1/2 by insulin and IGF1 with phospho-specific antibodies against Akt/PKB (p-Ser473) and ERK1/2 (p-Thr202/Tyr204). IGF1 and insulin both activated Akt/PKB strongly within minutes in A549 cells as they did in Saos-2/B10 cells; sustained activation of $\mathrm{Akt} / \mathrm{PKB}$ was observed in response to both IGF1 and insulin. ERK1/2 activation was less pronounced and transient.

Figure 10 summarizes dose-dependent activation of Akt/ PKB and ERK1/2 as well as regulation of proliferation and apoptosis in A549 cells. Insulin or IGFI both protected
A549 cells from apoptosis and stimulated DNA synthesis. As in Saos-2/B10 cells, IGF1 (at lower doses) and insulin (at higher doses) were more effective in increasing and maintaining Akt/PKB phosphorylation and protecting cells from apoptosis while regulation of ERK1/2 and stimulation of DNA synthesis was less sensitive.

We also tested the effects of IGFBP3 and of WT in A549 cells (not shown). For both test compounds, results were as found for Saos-2/B10 cells. rhIGFBP3 blocked the effects of IGF1 but not those of insulin; per se, it slightly enhanced apoptosis which appears consistent with a role for endogenous IGF1 in the survival of A549 cells; autocrine IGF1 may also be related to their lower IGF1R number and their lower sensitivity to insulin/IGF1 as compared with Saos-2/ B10 cells [10]. WT fully blocked IGF1- and insulin-stimulated Akt/PKB phosphorylation, and it decreased basal/ residual p-Akt/PKB within $30 \mathrm{~min}$ of exposure. WT also interfered with protection from apoptosis by both $1 \mathrm{nmol} / \mathrm{l}$ IGF1 and $100 \mathrm{nmol} / \mathrm{l}$ insulin, and, when present throughout $4 \mathrm{~h}$, increased apoptosis in the control condition.

\section{Discussion}

Osteosarcoma is a malignant bone tumour with an incidence peak coinciding with the adolescent growth spurt, a time when the hormonal milieu is characterized by high GH, IGF1 and insulin levels. Osteosarcoma growth may be particularly dependent on IGF1 $[12,16,18]$. The Saos-2/
Fig. 8 Effects of IGF1, insulin, glargine, and FCS compared in Saos-2/B10 cells. Cells were exposed to IGF1, insulin, glargine, or FCS as described for Figs. 2 and 4. Top panel Western blot showing p-Akt/ PKB, p-ERK1/2, bottom panel stimulation of DNA synthesis and inhibition of apoptosis, expressed relative to control ( $\log$ scale), $n=7 . c$ denotes control, $* * * p<0.0001$

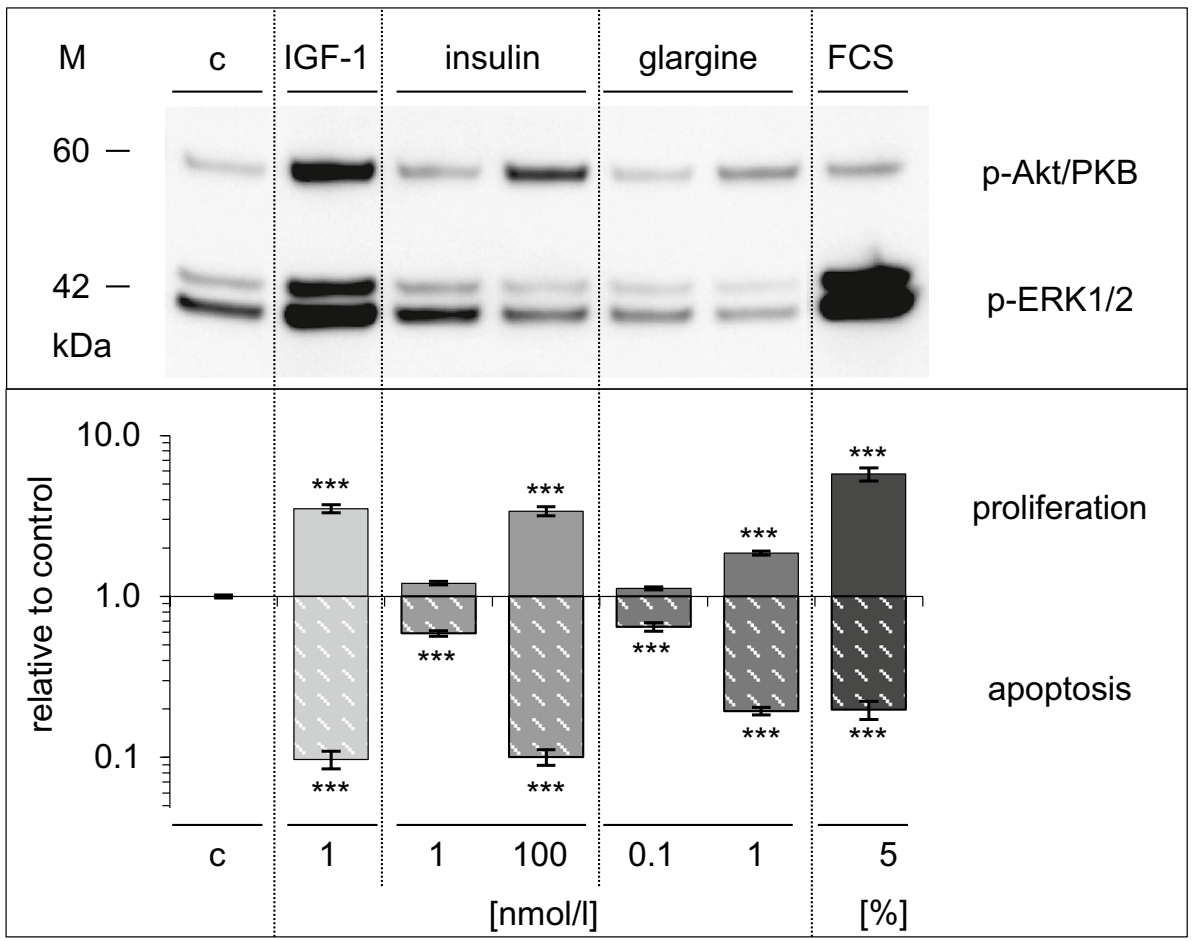




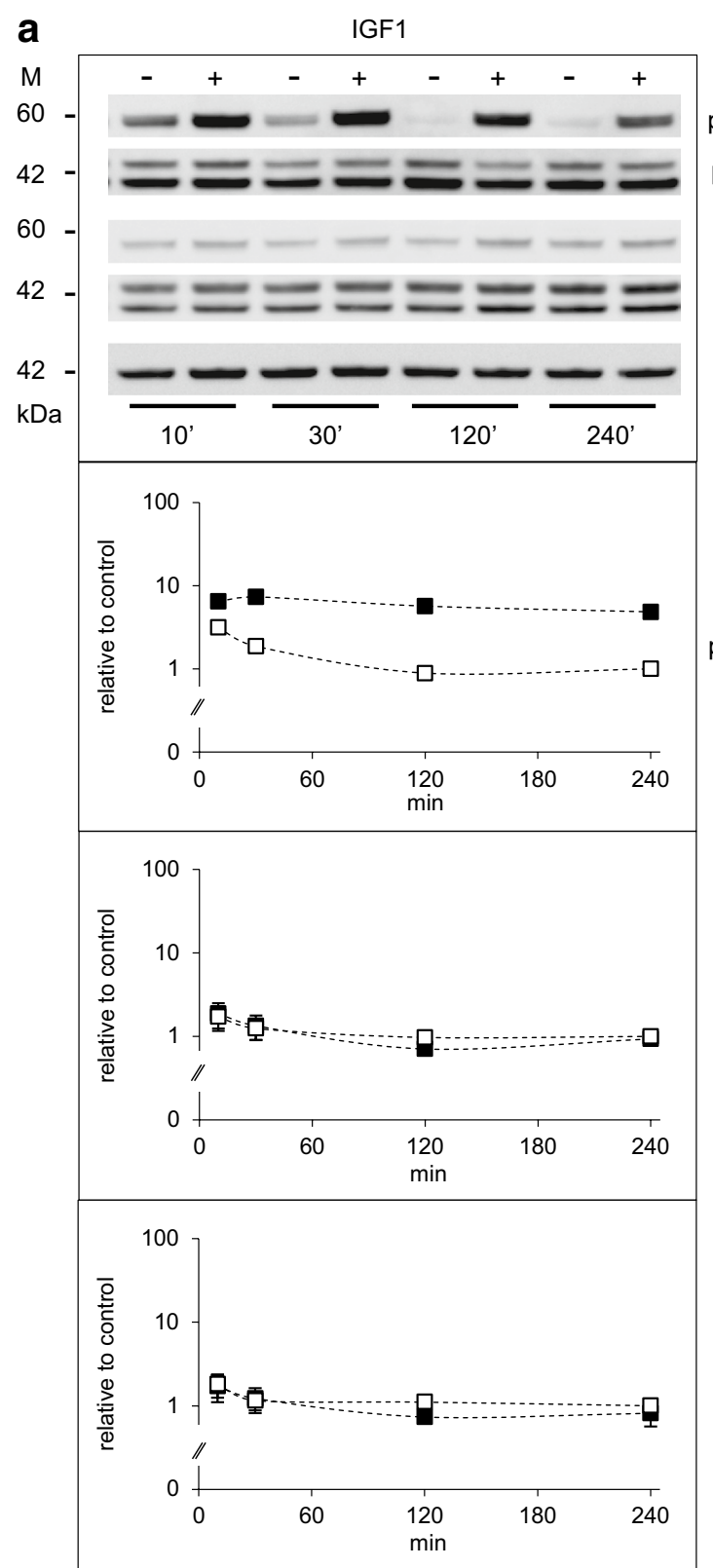

Fig. 9 Time-dependent activation of Akt/PKB and ERK1/2 by IGF1 and insulin in A549 cells. Representative Western blots are shown on top; quantification of signals from two independent experiments (with duplicates) below. Abundance of $\mathrm{p}-\mathrm{Akt} / \mathrm{PKB}$ and $\mathrm{p}$-ERK1/2 is shown

B10 subline model has been well characterized and used extensively to elucidate actions of IGF1, IGF2, IGFBPs, insulin, and analogues [10, 13, 17, 29, 32, 33].

IGF1 and insulin activated Akt/PKB in Saos-2/B10 cells and concomitantly protected against apoptosis $\left(\mathrm{EC}_{50}\right.$ for inhibition of apoptosis, $0.04 \mathrm{nmol} / 1$ for IGF1, $1 \mathrm{nmol} / 1$ for insulin). Saos-2/B10 cells were (approximately 10-fold) more sensitive to IGF1 in terms of inhibition of apoptosis than with regard to stimulation of DNA synthesis. In the case of insulin (and of glargine), this difference was even

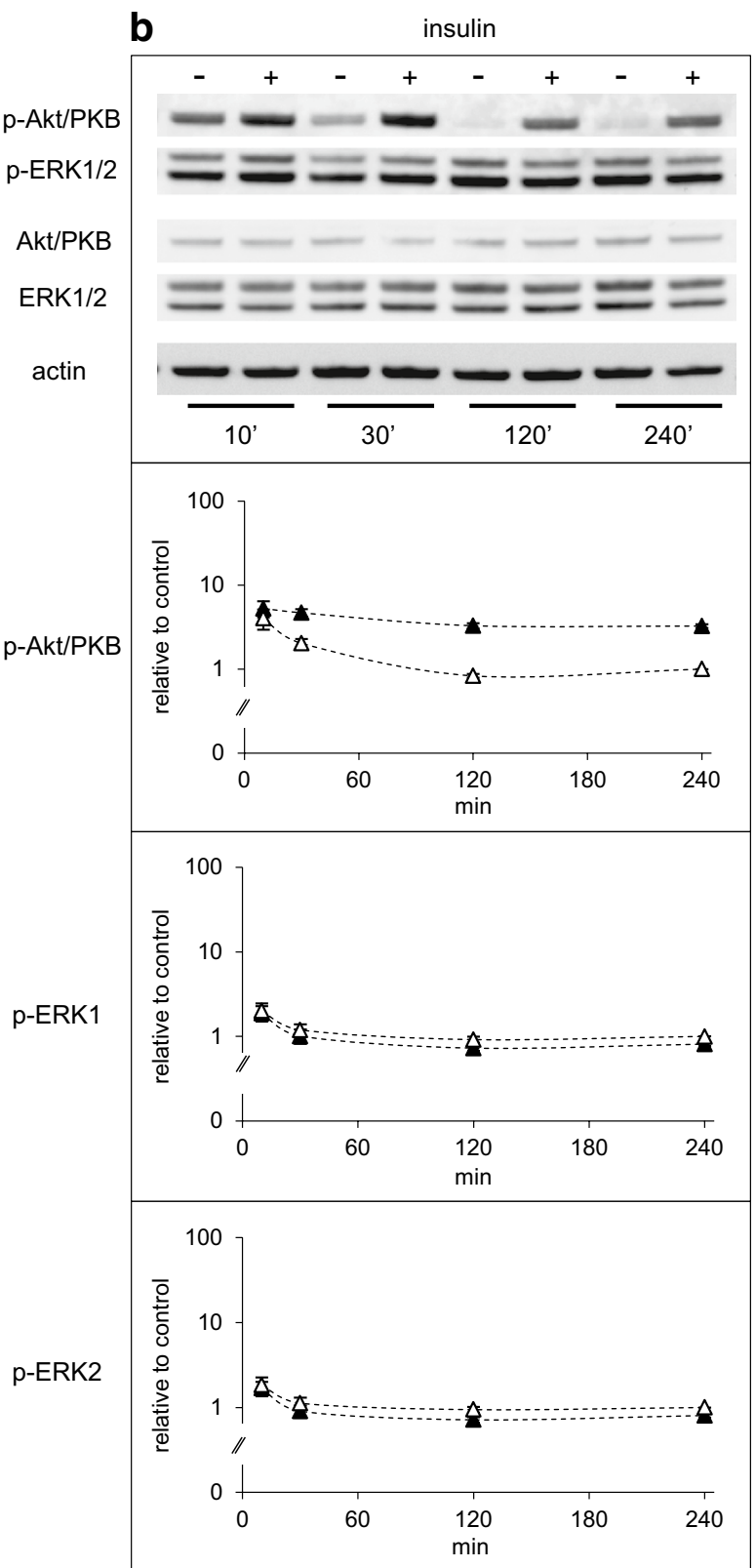

relative to control $(4 \mathrm{~h})$. Cells were exposed to vehicle (empty symbols), to $1 \mathrm{nmol} / 1$ IGF1 (filled squares) or to $100 \mathrm{nmol} / 1$ insulin (filled triangles) as outlined in Fig. 1b, and incubations were stopped after 10, 30, 120, and 240 min (as in Fig. 3). $M$ denotes markers

more pronounced, approximately 20-fold. Apoptosis was inhibited to a similar minimum by IGF1, insulin, or glargine, but higher concentrations of insulin or glargine were required. Effects of IGF1 but not those of insulin and glargine were blocked by IGFBP3. FCS-containing media (without addition of IGF1 or insulin) also activated Akt/ PKB and protected from apoptosis (Fig. 8). Media containing 5\% FCS were more effective than IGF1 or insulin in activating ERK1/2/MAPK and in stimulating DNA synthesis, but less potent than $1 \mathrm{nmol} / \mathrm{l} \mathrm{IGF} 1$ or $100 \mathrm{nmol} / \mathrm{l}$ insulin 
Fig. 10 Dose-dependent effects of IGF1 and insulin on signalling, proliferation, and apoptosis in A549 cells. Cells were exposed to IGF1 or insulin as described for Figs. 2 and 4, and data are shown as in Fig. 8 for Saos-2/B10 cells. Top panel Western blot showing p-Akt/ PKB, p-ERK1/2, bottom panel stimulation of DNA synthesis $(n=7$ in triplicate) and inhibition of apoptosis $(n=2$ in triplicate), expressed relative to control (log scale). $c$ denotes control, $* * * p<0.0001$

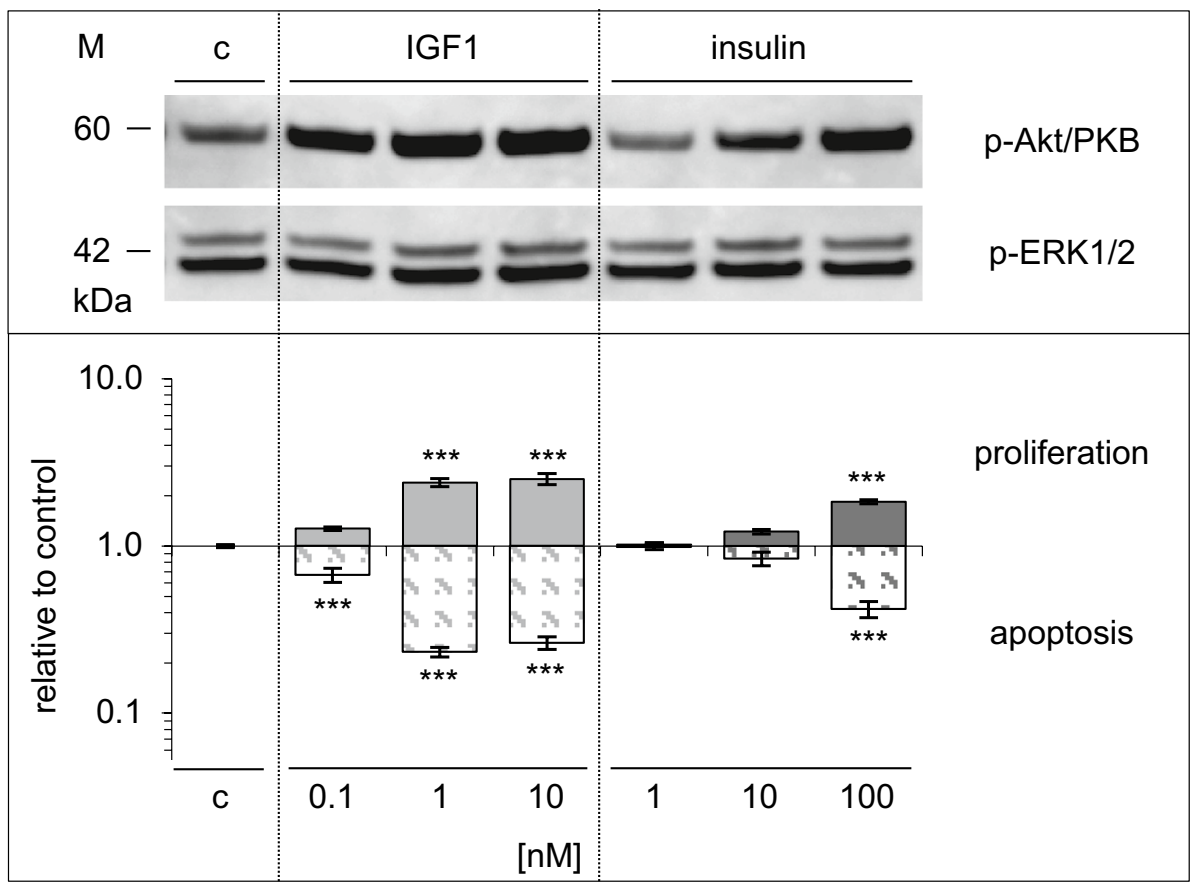

in protecting Saos-2/B10 cells from apoptosis within $4 \mathrm{~h}$, and 5\% FCS was also less effective in stimulating p-Akt/ $\mathrm{PKB}$ within $30 \mathrm{~min}$ (Fig. 8). These findings together with the blocking effects of WT are in line with the notion that signalling through IGF1R/IR and Akt/PKB promotes survival of Saos-2/B10 cells upon serum withdrawal. Most previous studies assessed DNA synthesis in vitro and suggested that insulin concentrations that stimulated DNA synthesis in vitro were probably not reached in vivo [13, 34]. However, as we show here, this is not necessarily the case when considering antiapoptotic effects. Insulin (either endogenous or exogenous) could well reach concentrations which may contribute to survival of selected malignant tumour cells, especially in insulin-resistant patients. In view of the low concentrations required for apoptosis prevention, the potential of insulin and analogues in maintaining certain malignant cells in a vital state may have been underestimated. It appears that characterization of IR binding agonists should include assays on prevention of apoptosis and not restrict the focus on mitogenic potency. It has been proposed that specificity of ligand-receptor interactions defines biological response. Usually, insulin promotes proliferation of tumour cells only at higher concentrations than IGF1, possibly since it predominantly acts via type 1 IGFRs. Glargine is more potent than insulin with regard to IGF1R phosphorylation [35-37] and with regard to stimulation of proliferation [7, 9, 13, 21, 35]. Glargine is also (around seven to eight times) more potent than insulin with regard to inhibition of apoptosis. However, insulin and IGF1 have overlapping receptor binding characteristics and share intracellular signalling pathways, including IR substrates, PI3K- and ERK-dependent pathways [38]; specificity of insulin versus IGF action is far from being understood [39].

An important finding of our study is that IGF1 and insulin effectively increase and maintain Akt/PKB in its phosphorylated state and concomitantly protect the cells from undergoing apoptosis. Inhibition of apoptosis was sensitive to WT, a widely used inhibitor of the PI3K-Akt/PKB axis [40-42]. IGF1 and insulin induced a prompt, strong and sustained activation of Akt/PKB while ERK1/2 was activated only transiently, and only by IGF1 and not by insulin. Compounds preventing activation of ERK1/2 (UO126 and PD98059) failed to inhibit the apoptosis-preventing effects of IGF1 and insulin. Our observation that insulin effectively prevented apoptosis yet barely activated ERK1/2 also suggests that prevention of apoptosis by insulin or IGF1 does not depend on activation of ERK1/2. In this context, it appears less important at which receptor(s) signalling initiates, as signals finally converge at the level of PI3K to prevent apoptosis. Therefore, we propose that in vitro safety tests with insulin analogues should include assays addressing apoptosis and activation/maintenance of PI3K-dependent signalling, rather than activation of different IR/IGF1R types. Indeed, Akt/PKB is central to a well-studied survival pathway and a known protooncogene [43-46]. Akt/ PKB is frequently hyperactivated in osteosarcoma [19]. It promotes cell survival by phosphorylating and inactivating several pro-apoptotic targets, such as Bad and the forkhead transcription factors. Overall, Akt/PKB is one of the most 
frequently activated kinases in human cancer, and ectopic expression of a dominant-negative kinase-dead variant inhibited the ability of IGF1 to prevent apoptosis in Saos-2 cells [11]. Our findings with Saos-2/B10 cells concur with the report by Kalaany and Sabatini [20] who also came to the conclusion that continuous exposure to insulin-like signals possibly more often helps tumour cells to survive than directly favours tumour growth progression by increasing mitogenesis.

Insulin-regulated autophagy was reported recently to link diabetes and cancer [47]. Indeed, autophagy may induce or prevent cell death, dependent on the cells under study and the context, as also reported for osteosarcoma cells [48]. Microtubule-associated protein 1 light chain 3 (MAP-LC3) is converted from the LC3-I ( $16 \mathrm{kDa})$ to the active LC3-II $(14 \mathrm{kDa})$ form indicating increased autophagy flux. In our cell culture conditions, LC3-II did not appear to increase after serum withdrawal, and decreased only to a minor extent by IGF1 and insulin after 2 and $4 \mathrm{~h}$ (supplemental Fig. 1). Within the short time frame of our experimental setting, we found no obvious correlation between phosphorylation of $\mathrm{Akt} / \mathrm{PKB}$ and induction of autophagy, in contrast to the strong correlation between phosphorylation of Akt/PKB and inhibition of apoptosis. Our study does not allow to clarify or exclude a potential role of autophagy in the regulation of apoptosis.

We show experiments just for two cell lines, and results therefore should be confirmed in other models. In both cell lines, we observed the same close relationship between activation and maintenance of $\mathrm{Akt} / \mathrm{PKB}$ and protection from apoptosis. However, there were quantitative differences regarding potencies of IR/IGF1R agonists which may be due to known variations in expression levels of IGF1 and IGF1R [10]. It has to be kept in mind that Saos-2/B10 cells are particularly sensitive to IR/IGF1R agonists; other tumour cell types could be less sensitive. Another limitation of our study was the use of pharmacological inhibitors to downregulate the activation of Akt/PKB and ERK1/2. Such compounds could exert unspecific effects, especially with longer incubation times. However, we have focused our study on the regulation of apoptosis in the short term (up to $4 \mathrm{~h}$ ) where fewer overall toxic effects are expected. Conclusive evidence for the requirement of $\mathrm{Akt} / \mathrm{PKB}$ in insulin/IGF1-induced survival of Saos-2/B10 cells requires specific knock-down (e.g., by siRNAs). To test if their activation is not only required for insulin/IGF1 effects but also sufficient for regulation of survival ectopic activation of downstream components (as, e.g., in [49]) would be required.

In healthy humans, insulin is secreted in pulsatile bursts [50]. Not only loss of early phase insulin response to glucose but also the disruption of high frequency pattern of insulin secretion during fasting is characteristic of beta cell failure in type 2 diabetes [51]. Indeed, insulin given as intravenous pulses has greater glucoregulatory activity than insulin by continuous infusion $[52,53]$; this may account for increased insulin dose requirement of flat profile long-acting insulin analogues [54]. Normal regulation of blood glucose in healthy subjects with pulsatile insulin secretion includes periods of low insulin concentrations. In contrast, standard basal insulin replacement modalities fail to mimic this physiological insulin secretion pattern. Our in vitro study addressed insulin/IGF-dependent regulation of apoptosis and phosphorylation of Akt/PKB under conditions of continuous or interrupted stimulation. Within the $4 \mathrm{~h}$ following FCS withdrawal IGF1 and insulin effectively activated $\mathrm{Akt} / \mathrm{PKB}$ and prevented apoptosis, also when added with a 2-h delay (Fig. 5). Moreover, p-Akt/PKB was decreased and protection from apoptosis was lost when IGF1 was blocked by later addition of IGFBP3 for at least 2 h (Fig. 6).

Our results indicate that apoptosis is prevented in Saos-2/B10 and A549 cells by signalling through the PI3K$\mathrm{Akt} / \mathrm{PKB}$ pathway which is activated and remains active upon continuous exposure to IGF1 or insulin. Furthermore, lower concentrations of IR/IGF1R agonists are required for preventing cell death than for stimulating cell proliferation.

Acknowledgements We thank Dora Schmid for excellent technical support. This work was supported by the Swiss National Science Foundation, Grant 32-46808.96 to CS. MN was supported by the Olga Mayenfisch Foundation and Cost Action BM0602, European Cooperation in Science and Technology.

\section{Compliance with ethical standards}

Conflict of interest The authors declare that there is no duality of interest associated with this manuscript.

Open Access This article is distributed under the terms of the Creative Commons Attribution 4.0 International License (http:// creativecommons.org/licenses/by/4.0/), which permits unrestricted use, distribution, and reproduction in any medium, provided you give appropriate credit to the original author(s) and the source, provide a link to the Creative Commons license, and indicate if changes were made.

\section{References}

1. Guevara-Aguirre J, Rosenbloom AL (2015) Obesity, diabetes and cancer: insight into the relationship from a cohort with growth hormone receptor deficiency. Diabetologia 58(1):37-42. doi:10.1007/s00125-014-3397-3

2. Junnila RK, List EO, Berryman DE, Murrey JW, Kopchick JJ (2013) The GH/IGF-1 axis in ageing and longevity. Nat Rev Endocrinol 9(6):366-376. doi:10.1038/nrendo.2013.67

3. Pollak M (2012) The insulin and insulin-like growth factor receptor family in neoplasia: an update. Nat Rev Cancer 12(3):159-169. doi:10.1038/nrc3215 
4. Heuson JC, Coune A, Heimann R (1967) Cell proliferation induced by insulin in organ culture of rat mammary carcinoma. Exp Cell Res 45(2):351-360

5. Liefvendahl E, Arnqvist HJ (2008) Mitogenic effect of the insulin analogue glargine in malignant cells in comparison with insulin and IGF-I. Horm Metab Res 40(6):369-374. doi:10.105 5/s-2008-1062739

6. Osborne CK, Bolan G, Monaco ME, Lippman ME (1976) Hormone responsive human breast cancer in long-term tissue culture: effect of insulin. Proc Natl Acad Sci USA 73(12):4536-4540

7. Shukla A, Grisouard J, Ehemann V, Hermani A, Enzmann H, Mayer D (2009) Analysis of signaling pathways related to cell proliferation stimulated by insulin analogs in human mammary epithelial cell lines. Endocr Relat Cancer 16(2):429-441. doi:10.1677/ERC-08-0240

8. Svendsen AM, Winge SB, Zimmermann M, Lindvig AB, Warzecha CB, Sajid W, Horne MC, De Meyts P (2014) Down-regulation of cyclin $\mathrm{G} 2$ by insulin, IGF-I (insulin-like growth factor 1) and $X 10$ (AspB10 insulin): role in mitogenesis. Biochem $J$ 457(1):69-77. doi:10.1042/BJ20130490

9. Weinstein D, Simon M, Yehezkel E, Laron Z, Werner H (2009) Insulin analogues display IGF-I-like mitogenic and anti-apoptotic activities in cultured cancer cells. Diabetes Metab Res Rev 25(1):41-49. doi:10.1002/dmrr.912

10. Bostedt KT, Schmid C, Ghirlanda-Keller C, Olie R, Winterhalter KH, Zapf J (2001) Insulin-like growth factor (IGF) I downregulates type 1 IGF receptor (IGF $1 \mathrm{R}$ ) and reduces the IGF I response in A549 non-small-cell lung cancer and Saos-2/B-10 osteoblastic osteosarcoma cells. Exp Cell Res 271(2):368-377. doi:10.1006/excr.2001.5388

11. Grey A, Chen Q, Xu X, Callon K, Cornish J (2003) Parallel phosphatidylinositol-3 kinase and p42/44 mitogen-activated protein kinase signaling pathways subserve the mitogenic and antiapoptotic actions of insulin-like growth factor I in osteoblastic cells. Endocrinology 144(11):4886-4893. doi:10.1210/ en.2003-0350

12. Kappel CC, Velez-Yanguas MC, Hirschfeld S, Helman LJ (1994) Human osteosarcoma cell lines are dependent on insulin-like growth factor I for in vitro growth. Cancer Res 54(10):2803-2807

13. Kurtzhals P, Schaffer L, Sorensen A, Kristensen C, Jonassen I, Schmid C, Trub T (2000) Correlations of receptor binding and metabolic and mitogenic potencies of insulin analogs designed for clinical use. Diabetes 49(6):999-1005

14. Ohlsson C, Kley N, Werner H, LeRoith D (1998) p53 regulates insulin-like growth factor-I (IGF-I) receptor expression and IGFI-induced tyrosine phosphorylation in an osteosarcoma cell line: interaction between p53 and Sp1. Endocrinology 139(3):11011107. doi:10.1210/endo.139.3.5832

15. Pollak MN, Polychronakos C, Richard M (1990) Insulinlike growth factor I: a potent mitogen for human osteogenic sarcoma. J Natl Cancer Inst 82(4):301-305

16. Rikhof B, de Jong S, Suurmeijer AJ, Meijer C, van der Graaf WT (2009) The insulin-like growth factor system and sarcomas. J Pathol 217(4):469-482. doi:10.1002/path.2499

17. Schmid C, Rutishauser J, Schlapfer I, Froesch ER, Zapf J (1991) Intact but not truncated insulin-like growth factor binding protein-3 (IGFBP-3) blocks IGF I-induced stimulation of osteoblasts: control of IGF signalling to bone cells by IGFBP-3-specific proteolysis? Biochem Biophys Res Commun 179(1):579-585

18. Schwartz GK, Tap WD, Qin LX, Livingston MB, Undevia SD, Chmielowski B, Agulnik M, Schuetze SM, Reed DR, Okuno SH, Ludwig JA, Keedy V, Rietschel P, Kraft AS, Adkins D, Van Tine BA, Brockstein B, Yim V, Bitas C, Abdullah A, Antonescu CR, Condy M, Dickson MA, Vasudeva SD, Ho
AL, Doyle LA, Chen HX, Maki RG (2013) Cixutumumab and temsirolimus for patients with bone and soft-tissue sarcoma: a multicentre, open-label, phase 2 trial. Lancet Oncol 14(4):371-382. doi:10.1016/S1470-2045(13)70049-4

19. Zhang J, Yu XH, Yan YG, Wang C, Wang WJ (2015) PI3K/ Akt signaling in osteosarcoma. Clin Chim Acta 444:182-192. doi:10.1016/j.cca.2014.12.041

20. Kalaany NY, Sabatini DM (2009) Tumours with PI3K activation are resistant to dietary restriction. Nature 458(7239):725731. doi:10.1038/nature07782

21. Varewijck AJ, Janssen JA (2012) Insulin and its analogues and their affinities for the IGF1 receptor. Endocr Relat Cancer 19(5):F63-F75. doi:10.1530/ERC-12-0026

22. Kuerzel GU, Shukla U, Scholtz HE, Pretorius SG, Wessels DH, Venter C, Potgieter MA, Lang AM, Koose T, Bernhardt E (2003) Biotransformation of insulin glargine after subcutaneous injection in healthy subjects. Curr Med Res Opin 19(1):34-40

23. Lucidi P, Porcellati F, Candeloro P, Cioli P, Andreoli AM, Marzotti S, Schmidt R, Bolli GB, Fanelli CG (2014) Glargine metabolism over $24 \mathrm{~h}$ following its subcutaneous injection in patients with type 2 diabetes mellitus: a dose-response study. Nutr Metab Cardiovasc Dis 24(7):709-716. doi:10.1016/j. numecd.2014.02.008

24. Pierre-Eugene C, Pagesy P, Nguyen TT, Neuille M, Tschank G, Tennagels N, Hampe C, Issad T (2012) Effect of insulin analogues on insulin/IGF1 hybrid receptors: increased activation by glargine but not by its metabolites M1 and M2. PLoS ONE 7(7):e41992. doi:10.1371/journal.pone.0041992

25. Sommerfeld MR, Muller G, Tschank G, Seipke G, Habermann P, Kurrle R, Tennagels N (2010) In vitro metabolic and mitogenic signaling of insulin glargine and its metabolites. PLoS ONE 5(3):e9540. doi:10.1371/journal.pone.0009540

26. Rodan SB, Imai Y, Thiede MA, Wesolowski G, Thompson D, Bar-Shavit Z, Shull S, Mann K, Rodan GA (1987) Characterization of a human osteosarcoma cell line (Saos-2) with osteoblastic properties. Cancer Res 47(18):4961-4966

27. Rodan SB, Wesolowski G, Ianacone J, Thiede MA, Rodan GA (1989) Production of parathyroid hormone-like peptide in a human osteosarcoma cell line: stimulation by phorbol esters and epidermal growth factor. J Endocrinol 122(1):219-227

28. Buckbinder L, Talbott R, Velasco-Miguel S, Takenaka I, Faha B, Seizinger BR, Kley N (1995) Induction of the growth inhibitor IGF-binding protein 3 by p53. Nature 377(6550):646-649. doi:10.1038/377646a0

29. Schmid C, Keller C, Gosteli-Peter M, Zapf J (1999) Mitogenic and antiapoptotic effects of insulin-like growth factor binding protein-6 in the human osteoblastic osteosarcoma cell line Saos-2/B-10. Biochem Biophys Res Commun 263(3):786-789. doi:10.1006/bbrc.1999.1451

30. Lieber M, Smith B, Szakal A, Nelson-Rees W, Todaro G (1976) A continuous tumor-cell line from a human lung carcinoma with properties of type II alveolar epithelial cells. Int J Cancer 17(1):62-70

31. Fogh J, Wright WC, Loveless JD (1977) Absence of HeLa cell contamination in 169 cell lines derived from human tumors. J Natl Cancer Inst 58(2):209-214

32. Schmid C, Ghirlanda-Keller C, Zapf J (2001) Effects of IGF-I and -II, IGF binding protein-3 (IGFBP-3), and transforming growth factor-beta (TGF-beta) on growth and apoptosis of human osteosarcoma Saos-2/B-10 cells: lack of IGF-independent IGFBP-3 effects. Eur J Endocrinol 145(2):213-221

33. Kiefer MC, Schmid C, Waldvogel M, Schlapfer I, Futo E, Masiarz FR, Green K, Barr PJ, Zapf J (1992) Characterization of recombinant human insulin-like growth factor binding proteins 4, 5, and 6 produced in yeast. J Biol Chem 267(18):12692-12699 
34. Pollak M (2012) The insulin receptor/insulin-like growth factor receptor family as a therapeutic target in oncology. Clin Cancer Res 18(1):40-50. doi:10.1158/1078-0432.CCR-11-0998

35. Eckardt K, May C, Koenen M, Eckel J (2007) IGF-1 receptor signalling determines the mitogenic potency of insulin analogues in human smooth muscle cells and fibroblasts. Diabetologia 50(12):2534-2543. doi:10.1007/s00125-007-0815-9

36. Varewijck AJ, Goudzwaard JA, Brugts MP, Lamberts SW, Hofland LJ, Janssen JA (2010) Insulin glargine is more potent in activating the human IGF-I receptor than human insulin and insulin detemir. Growth Horm IGF Res 20(6):427-431. doi:10.1016/j.ghir.2010.10.002

37. Yehezkel E, Weinstein D, Simon M, Sarfstein R, Laron Z, Werner H (2010) Long-acting insulin analogues elicit atypical signalling events mediated by the insulin receptor and insulinlike growth factor-I receptor. Diabetologia 53(12):2667-2675. doi:10.1007/s00125-010-1899-1

38. Siddle K (2011) Signalling by insulin and IGF receptors: supporting acts and new players. J Mol Endocrinol 47(1):R1-R10. doi: 10.1530/JME-11-002210

39. Boller S, Joblin BA, Xu L, Item F, Trub T, Boschetti N, Spinas GA, Niessen M (2012) From signal transduction to signal interpretation: an alternative model for the molecular function of insulin receptor substrates. Arch Physiol Biochem 118(3):148 155. doi:10.3109/13813455.2012.671333

40. Arcaro A, Wymann MP (1993) Wortmannin is a potent phosphatidylinositol 3-kinase inhibitor: the role of phosphatidylinositol 3,4,5-trisphosphate in neutrophil responses. Biochem $\mathrm{J}$ 296(Pt 2):297-301

41. Galetic I, Andjelkovic M, Meier R, Brodbeck D, Park J, Hemmings BA (1999) Mechanism of protein kinase B activation by insulin/insulin-like growth factor-1 revealed by specific inhibitors of phosphoinositide 3-kinase-significance for diabetes and cancer. Pharmacol Ther 82(2-3):409-425

42. Powis G, Bonjouklian R, Berggren MM, Gallegos A, Abraham R, Ashendel C, Zalkow L, Matter WF, Dodge J, Grindey G et al (1994) Wortmannin, a potent and selective inhibitor of phosphatidylinositol-3-kinase. Cancer Res 54(9):2419-2423

43. Hers I, Vincent EE, Tavare JM (2011) Akt signalling in health and disease. Cell Signal 23(10):1515-1527. doi:10.1016/j. cellsig.2011.05.004

44. Robey RB, Hay N (2009) Is Akt the "Warburg kinase"?-Aktenergy metabolism interactions and oncogenesis. Semin Cancer Biol 19(1):25-31. doi:10.1016/j.semcancer.2008.11.010
45. Schultze SM, Hemmings BA, Niessen M, Tschopp O (2012) PI3K/AKT, MAPK and AMPK signalling: protein kinases in glucose homeostasis. Expert Rev Mol Med 14:e1. doi:10.1017/ S1462399411002109

46. Zoncu R, Efeyan A, Sabatini DM (2011) mTOR: from growth signal integration to cancer, diabetes and ageing. Nat Rev Mol Cell Biol 12(1):21-35. doi:10.1038/nrm3025

47. Hua F, Li K, Yu JJ, Lv XX, Yan J, Zhang XW, Sun W, Lin H, Shang S, Wang F, Cui B, Mu R, Huang B, Jiang JD, Hu ZW (2015) TRB3 links insulin/IGF to tumour promotion by interacting with p62 and impeding autophagic/proteasomal degradations. Nat Commun 6:7951. doi:10.1038/ncomms8951

48. Osasan S, Zhang M, Shen F, Paul PJ, Persad S, Sergi C (2016) Osteogenic sarcoma: a 21st century review. Anticancer Res 36(9):4391-4398. doi:10.21873/anticanres.10982

49. Buzzi F, Xu L, Zuellig RA, Boller SB, Spinas GA, Hynx D, Chang Z, Yang Z, Hemmings BA, Tschopp O, Niessen M (2010) Differential effects of protein kinase B/Akt isoforms on glucose homeostasis and islet mass. Mol Cell Biol 30(3):601-612. doi:10.1128/MCB.00719-09

50. Porksen N, Munn S, Steers J, Vore S, Veldhuis J, Butler P (1995) Pulsatile insulin secretion accounts for $70 \%$ of total insulin secretion during fasting. Am J Physiol 269(3 Pt 1):E478-E488

51. Hollingdal M, Juhl CB, Pincus SM, Sturis J, Veldhuis JD, Polonsky KS, Porksen N, Schmitz O (2000) Failure of physiological plasma glucose excursions to entrain high-frequency pulsatile insulin secretion in type 2 diabetes. Diabetes 49(8):1334-1340

52. Paolisso G, Scheen AJ, Giugliano D, Sgambato S, Albert A, Varricchio M, D’Onofrio F, Lefebvre PJ (1991) Pulsatile insulin delivery has greater metabolic effects than continuous hormone administration in man: importance of pulse frequency. J Clin Endocrinol Metab 72(3):607-615. doi:10.1210/jcem-72-3-607

53. Paolisso G, Sgambato S, Varricchio M, Scheen AJ, D’Onofrio F, Lefebvre P (1992) Insulin effects on glucose kinetics in noninsulin-dependent diabetic patients with secondary failure to hypoglycaemic agents: role of different modes and rates of delivery. Eur J Med 1(5):261-267

54. Schmid C, Krayenbuhl P, Wiesli P (2009) Increased insulin dose requirement of long-acting insulin analogues in obese patients with type 2 diabetes. Diabetologia 52(12):2668-2669. doi:10.1007/s00125-009-1534-1 